\title{
Effect of water stress on leaf nutrient status and frequency of irrigation in various cultivars of kiwifruit
}

\author{
Preet Pratima $^{1}$, N. Sharma ${ }^{2}$ and Chaitanya Belsare ${ }^{3}$ \\ ${ }^{1}$ Department of Fruit Science, Dr Y. S. Parmar University of Horticulture and Forestry, Nauni, Solan -173230 \\ (H. P.), INDIA \\ ${ }^{2}$ Dr Y. S. Parmar University of Horticulture and Forestry, Nauni, Solan -173230 (H. P.), INDIA \\ ${ }^{3}$ Department of Fruit Science, Dr Y. S. Parmar University of Horticulture and Forestry, Nauni, Solan -173230 \\ (H. P.), INDIA \\ *Corresponding author. E-mail: preetepitome@gmail.com \\ Received: September 16, 2017; Revised received: October 27, 2017; Accepted: February 8, 2018
}

\begin{abstract}
The five cultivars of kiwifruit viz., Allison, Hayward, Abbott, Monty and Bruno during the years 2011 and 2012 in the Department of Fruit Science, Dr. Y. S. Parmar University of Horticulture and Forestry, Solan, Himachal Pradesh, India. Two irrigation treatments i.e. standard irrigation (at $80 \%$ field capacity) and deficit irrigation (at $60 \%$ F C) were applied to these cultivars from March to October with three replications in Randomized Block Design (RBD). The leaf nutrient content (\%) and frequency of irrigation (irrigation interval in days) were investigated in kiwifruit in response to these irrigation treatments. The leaf nitrogen $(\mathrm{N})$, phosphorus $(\mathrm{P})$, Potassium $(\mathrm{K})$, Calcium $(\mathrm{Ca})$ and Magnesium (Mg) contents varied with cultivars under two irrigation regimes. The leaf $\mathrm{N}$ content and Ca content (\%) was observed highest in cultivar Monty; P content in Allison; K content in Hayward; Mg content (\%) in Abbott and Monty under standard irrigation treatment. These nutrient contents reduced significantly at $0.05 \%$ level of significance with deficit irrigation treatment in different cultivars. The \% reduction in these nutrients with deficit irrigation treatment was found to be highest in cultivar Hayward and the least in Bruno. The total number of irrigation applied under standard and deficit irrigation were 16 and 10 respectively, during both the years. The response of Bruno cultivar in terms of leaf nutrient content under water deficit condition is much better in comparison to all other cultivars. Bruno is considered to be drought tolerant cultivar and Hayward to be drought sensitive. Thus, the Bruno cultivar should be preferred for cultivation in water scarce regions.
\end{abstract}

Keywords: Deficit irrigation, Irrigation frequency, Kiwifruit, Nutrient status

\section{INTRODUCTION}

The kiwifruit or Chinese gooseberry (Actinidia deliciosa Chev.) is a deciduous fruit vine, native to Yangtze valley of south and central China (Ferguson, 1984). In India, it can be grown successfully in areas experiencing 700-800 chilling hours (no. of hours during which temperature remains at or below $7^{0} \mathrm{C}$ during the winter season) and situated at elevation of 800-1500 m above mean sea level where, the winters are cold and summers are warm and humid, and receive well distributed annual rainfall of about $150 \mathrm{~cm}$ (Anonymous, 2005). The economic returns from kiwifruit depend strongly on fruit size, which are in turn directly affected by availability of water (Miller et al., 1998). Kiwifruit requires very frequent irrigation to sustain an adequate plant water status because of its low stomatal regulation (Beutel, 1990). The deficit irrigation reduces the transport of mineral ions through soil to the roots and through the plants. The demand for minerals by shoots and roots get changed as a result of drought stress. Drought stress modifies the uptake of mineral ions by the roots and the deficiencies or accumulation of ions resulted in disruption of metabolism in plants. During drought, the growth rate may be reduced to the extent, so that plant mineral content may be relatively stable (Blum, 2011).

Nitrogen metabolism is the most important factor that influences plant growth and performance. Disruption in $\mathrm{N}$ - metabolism is a crucial in-plant injury under the water deficit conditions. The reduction of nitrate uptake and decrease in nitrate reductase activity under water stress (Seyed et al., 2012). Phosphorus is a major essential element for plants and deficiency of this nutrient primarily reduces $\mathrm{CO}_{2}$ assimilation in leaf photosynthesis (Jacob and Lawlor, 1992). The reduction in biomass production in the source leaves affects growth of the plant (De Groot et al., 2001). The decrease in leaf number and size is one of the earliest and most reliable responses of P-deficiency on the plant (Lynch et al., 1991). Leaf expansion occurs due to cell multiplication and elongation of the newly formed 
cells in plants and turgor pressure is a crucial factor for cell expansion (Munns et al., 2000). The decrease in hydraulic conductivity of the root and stomatal conductance of the leaf, resulting in a severe reduction of leaf expansion under P-deficiency, was also found to be similar to the response of nitrogen stress (Clarkson et al., 2000). During drought, the phosphate ion is likely to be unavailable to plants as it is tightly absorbed onto clay particles, thus only a small proportion of total soil phosphate is available in soil solution. The diffusion coefficient is $10^{4}$ to $10^{7}$ times lower than that of potassium, nitrate and ammonium. Potassium $(\mathrm{K})$ is an essential nutrient that affects most of the biochemical and physiological processes that influence plant growth and metabolism. It also contributes to the survival of plants exposed to various biotic and abiotic stresses (Min et al., 2013). Potassium plays a crucial role in turgor regulation within the guard cells during stomatal movement (Marschner, 2012). $\mathrm{K}$ is an essential nutrient and is also the most abundant cation in plants. The concentration of $\mathrm{K}^{+}$in the cytoplasm has consistently been found to be between 100 and 200 $\mathrm{mM}$ (Shabala and Pottosin, 2010), and apoplastic $\mathrm{K}^{+}$concentration may vary between 10 and 200 or even reach up to $500 \mathrm{mM}$ (White and Karley, 2010). K plays essential roles in enzyme activation, protein synthesis, photosynthesis, osmoregulation, stomatal movement, energy transfer, phloem transport, cation-anion balance and stress resistance ( Marschner, 2012). The low plant $\mathrm{K}$ status induces the synthesis of molecules, including reactive oxygen species (ROS) and phytohormones, such as auxin, ethylene and jasmonic acid (JA), as a result of its enhanced plant stress tolerance (Amtmann et al., 2008).

Water stress also affects plant mineral nutrition and disrupts ion homeostasis. Calcium plays an essential role in structural and func tional integrity of plant membrane and other structures. Decrease in plant $\mathrm{Ca} 2+$ content was reported in many plants, for example, approximately $50 \%$ decrease in $\mathrm{Ca} 2+$ in drought stressed maize leaves, while in roots $\mathrm{Ca} 2+$ concentration was higher compared to control (Seyed et al., 2012).

\section{MATERIALS AND METHODS}

The present investigation was carried out in the Department of Fruit Science, Dr. Y. S. Parmar University of Horticulture and Forestry, Solan, HP, India during the years 2011 and 2012. Twenty five year old uniform vines of kiwifruit twenty five-year-old uniform vines of five different kiwifruit cultivars viz., Allison, Abbott, Monty, Hayward and Bruno were selected. These vines were planted at $6 \times 4 \mathrm{~m}$ spacing and trained on T-bar system. The vines of five cultivars were subjected to two irrigation levels viz., irrigation at $80 \%$ Field Capacity $\left(\mathrm{T}_{1}\right), 60 \% \mathrm{FC}\left(\mathrm{T}_{2}\right)$ with four replications, in Randomized Block Design. The irrigation treatments were applied to these plants from March to October and the mulching was applied in mid- March. The statistical analysis of the data was carried out as per method described by Gomez and Gomez (1984). The significance of different treatment's effect was tested at $5 \%$ level of significance as suggested by Cochran and Cox (1963).

The various parameters were observed by following the procedure mentioned below:

Leaf nutrient content: For estimation of leaf nutrient status of experimental trees, mature leaves with petioles were sampled in mid- August from middle portion of the current season's shoot, all around the periphery of the vine (Chapman, 1964). The samples were processed for nutrient analysis as per procedure outlined by Kenworthy (1964). Leaf samples were collected, brought directly to the laboratory, thoroughly washed by $0.1 \mathrm{~N} \mathrm{HCl}$, distilled water and finally with double distilled water. The washed samples were air dried in the shade by spreading on clean blotting papers and then dried in an oven at $65^{\circ} \mathrm{C}$ for 48 hours. The dried samples were ground and stored in butter paper bags for chemical analysis.

Digestion of leaf samples: For estimation of nitrogen, the digestion of one gram dried leaf samples was carried out in concentrated sulphuric acid in the presence of a digestion mixture of following chemicals:

Potassium sulphate $\left(\mathrm{K}_{2} \mathrm{SO}_{4}\right)$ : 400 parts

Copper sulphate $\left(\mathrm{CuSO}_{4} \quad\right.$ : 20 parts

Mercuric oxide $(\mathrm{HgO}) \quad: \quad 3$ parts

Selenium (Se) powder : : 1 part

For the estimation of other elements, the samples were digested in di-acid mixture prepared by mixing nitric acid and perchloric $\left(\mathrm{HClO}_{4}\right)$ acid in the ratio of $4: 1$, taking all relevant precautions as suggested by Piper (1966).

Estimation of leaf nutrients: After digestion, nitrogen was estimated by Micro-kjeldahl method (A.O. A. C., 1980). Twenty five millilitres of $4 \%$ boric acid solution containing mixed indicator (bromocresol green + methyl red) was taken in a conical flask and was placed in such a way that condenser outlet of distillation apparatus was dipped into boric acid solution. Then $10 \mathrm{ml}$ of the aliquot (digested) was taken and transferred to distillation flask of Micro-kjeldahl distillation apparatus. After adding the aliquot, the funnel of the apparatus was washed with 2-3 ml of distilled water and ten $\mathrm{ml}$ of $40 \%$ sodium hydroxide was added. Ammonia $\left(\mathrm{NH}_{3}\right)$ thus liberated was absorbed into the boric acid in conical flask. After completion of distillation, boric acid solution was titrated against standard sulphuric acid solution and nitrogen content was calculated on the basis of sulphuric acid solution used to neutralize the evolved ammonia and expressed in percentage on the dry weight basis.

Total phosphorus was determined by Vanado- Molybdate- Phosphoric Yellow colour Method (Jackson, 
1973). Five millilitres aliquot (digested) was pippetted out into $25 \mathrm{ml}$ volumetric flask and $5 \mathrm{ml}$ of vanadomolybdate reagent was added. Then solution was diluted to $25 \mathrm{ml}$ with distilled water and allowed to develop colour for half an hour. After development of colour, absorbance was recorded on Thermo Spectronic-20 D at $470 \mathrm{~nm}$ wavelength and a blank was run simultaneously to adjust the zero absorbance. Phosphorus content was then calculated from standard curve of phosphorus and expressed in $\%$ on dry weight basis.

Potassium, calcium and magnesium in the leaf extract were estimated on Perkins Elmen Atomic Absorption Spectrophotometer and expressed in percentage.

Frequency and number of irrigation: Frequency of the irrigation applied under different treatments was calculated by counting the number of days between two consecutive irrigations. The number of irrigations applied under these treatments over the growing period was calculated during both the year of study.

\section{RESULTS AND DISCUSSION}

\section{Leaf nutrient content}

Nitrogen: The leaf nitrogen content of kiwifruit vines was influenced significantly when subjected to different irrigation regimes during both the years (Table 1). The average leaf nitrogen content of different cultivars was reduced from $2.61 \%$ to $2.54 \%$ and $2.62 \%$ to 2.56 $\%$ under control and water stress treatment respective-

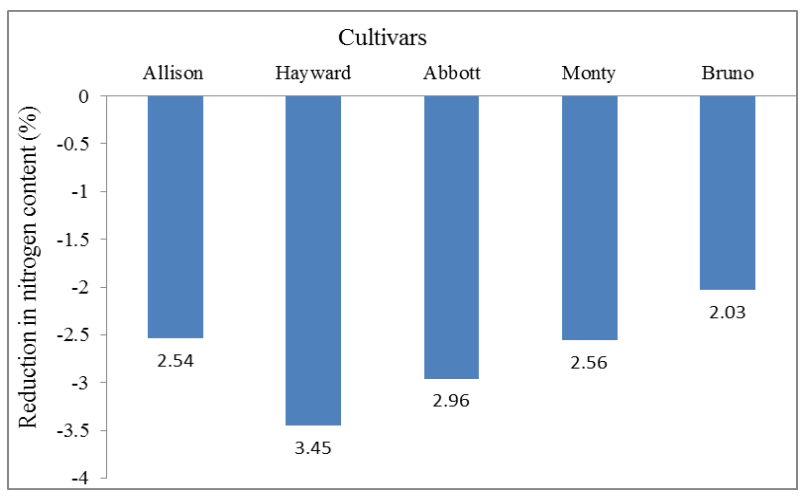

Fig. 1. \% reduction in nitrogen content of different cultivars of kiwifruit at irrigation at $60 \% \mathrm{FC}$ over $80 \% \mathrm{FC}$.

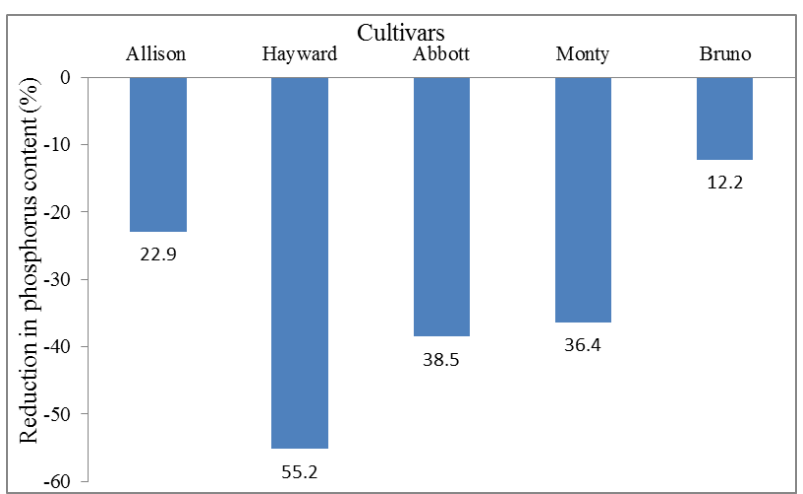

Fig. 2. \% reduction in phosphorus content of different cultivars of kiwifruit at irrigation at $60 \% \mathrm{FC}$ over $80 \% \mathrm{FC}$. ly, during the year 2011 and 2012. Among different cultivars the leaf nitrogen content under two water regimes was significantly variable during both the years of study. In cultivar Monty, significantly higher leaf nitrogen content $(3.08$ and $3.07 \%$ in 2011 and 2012, respectively) was recorded in the respective years whereas, the least was observed in cultivar Allison (2.13 and $2.15 \%$ in 2011 and 2012, respectively). Similarly, pooled data revealed that leaf nitrogen content was significantly higher in cultivar Monty (3.08\%) compared to the remaining four cultivars and significantly least (2.14\%) in cultivar Allison at $0.05 \%$ level of significance.

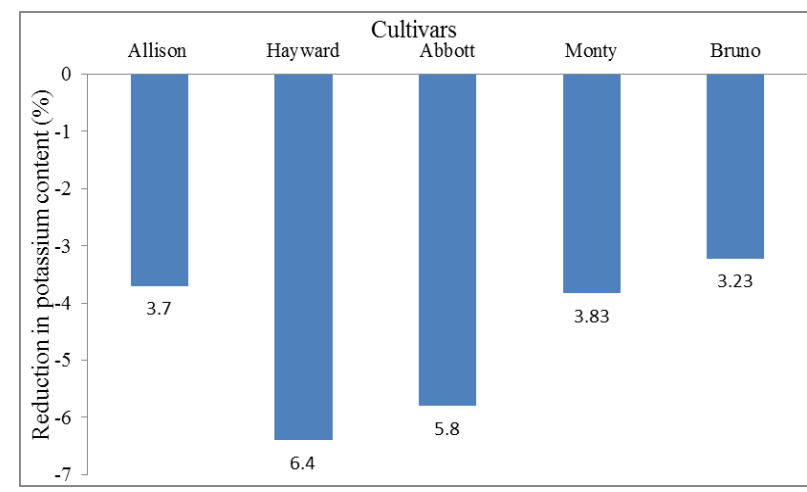

Fig. 3. \% reduction in potassium content of different cultivars of kiwifruit at irrigation at $60 \% \mathrm{FC}$ over $80 \% \mathrm{FC}$.

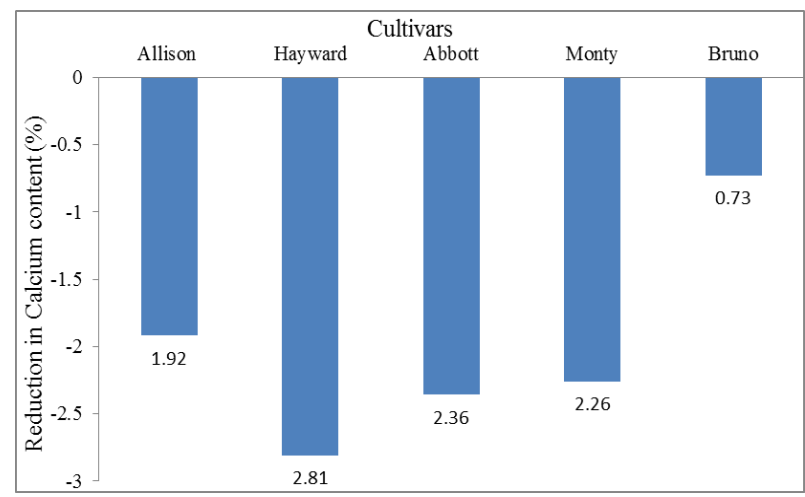

Fig. 4. \% reduction in calcium content of different cultivars of kiwifruit at irrigation at $60 \%$ FC over $80 \%$ FC.

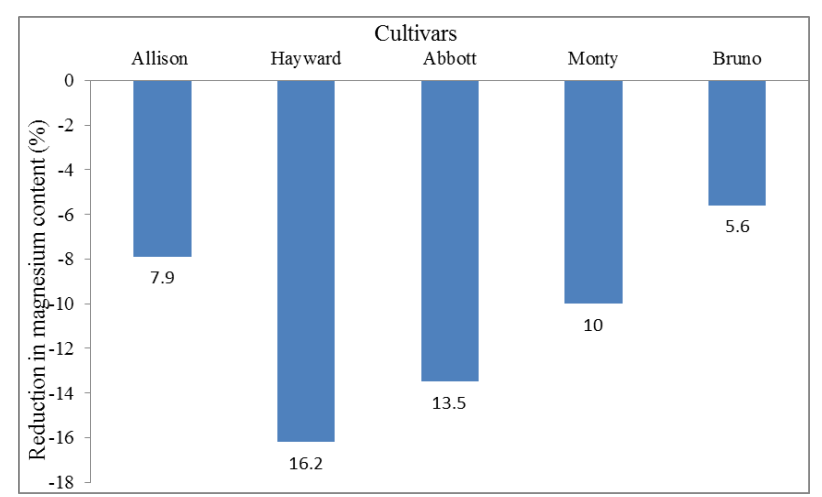

Fig. $5 \%$ reduction in magnesium content of different cultivars of kiwifruit at irrigation at $60 \% \mathrm{FC}$ over $80 \% \mathrm{FC}$. 
Preet Pratima et al. / J. Appl. \& Nat. Sci. 10 (1): 339 - 346 (2018)

Table 1. Effect of different irrigation levels on leaf nitrogen content (\%) of kiwifruit cultivars.

\begin{tabular}{|c|c|c|c|c|c|c|c|c|c|}
\hline \multirow{3}{*}{ Cultivars } & \multicolumn{2}{|c|}{2011} & \multirow{3}{*}{ Mean } & \multicolumn{2}{|c|}{2012} & \multirow{3}{*}{ Mean } & \multicolumn{2}{|c|}{ Pooled } & \multirow{3}{*}{ Mean } \\
\hline & \multicolumn{2}{|c|}{ Irrigation treatments } & & \multicolumn{2}{|c|}{ Irrigation treatments } & & \multicolumn{2}{|c|}{ Irrigation treatments } & \\
\hline & $80 \%$ FC & $60 \%$ FC & & $80 \%$ FC & $60 \%$ FC & & $80 \%$ FC & $60 \%$ FC & \\
\hline Allison & 2.16 & 2.09 & 2.13 & 2.17 & 2.13 & 2.15 & 2.17 & 2.11 & 2.14 \\
\hline Hayward & 2.89 & 2.77 & 2.83 & 2.90 & 2.82 & 2.86 & 2.90 & 2.80 & 2.85 \\
\hline Abbott & 2.70 & 2.62 & 2.66 & 2.71 & 2.63 & 2.67 & 2.71 & 2.63 & 2.67 \\
\hline Monty & 3.11 & 3.05 & 3.08 & 3.12 & 3.02 & 3.07 & 3.12 & 3.04 & 3.08 \\
\hline Bruno & 2.21 & 2.16 & 2.19 & 2.22 & 2.18 & 2.20 & 2.22 & 2.17 & 2.19 \\
\hline Mean & 2.61 & 2.54 & & 2.62 & 2.56 & & 2.62 & 2.55 & \\
\hline \multicolumn{2}{|l|}{$\mathrm{CD}_{0.05}$} & 2011 & 2012 & Pooled & & & & & \\
\hline \multicolumn{2}{|c|}{ Irrigation treatments (I) } & 0.01 & 0.01 & 0.01 & & & & & \\
\hline \multicolumn{2}{|c|}{ Cultivars (C) } & 0.01 & 0.02 & 0.01 & & & & & \\
\hline \multicolumn{2}{|c|}{$\begin{array}{l}\text { Irrigation treatments } \mathrm{X} \\
\text { Cultivars (I X C) }\end{array}$} & 0.01 & 0.02 & 0.01 & & & & & \\
\hline
\end{tabular}

Table 2. Effect of different irrigation levels on leaf phosphorus content (\%) of kiwifruit cultivars.

\begin{tabular}{|c|c|c|c|c|c|c|c|c|c|}
\hline \multirow{3}{*}{ Cultivars } & \multicolumn{2}{|c|}{2011} & \multirow{3}{*}{ Mean } & \multicolumn{2}{|c|}{2012} & \multirow{3}{*}{ Mean } & \multicolumn{2}{|c|}{$\begin{array}{c}\text { Pooled } \\
\end{array}$} & \multirow{3}{*}{ Mean } \\
\hline & \multicolumn{2}{|c|}{ Irrigation treatments } & & \multicolumn{2}{|c|}{ Irrigation treatments } & & \multicolumn{2}{|c|}{ Irrigation treatments } & \\
\hline & $80 \%$ FC & $60 \%$ FC & & $80 \%$ FC & $60 \%$ FC & & $80 \%$ FC & $60 \%$ FC & \\
\hline Allison & 0.17 & 0.13 & 0.15 & 0.18 & 0.14 & 0.16 & 0.18 & 0.14 & 0.16 \\
\hline Hayward & 0.14 & 0.06 & 0.10 & 0.15 & 0.07 & 0.11 & 0.15 & 0.07 & 0.11 \\
\hline Abbott & 0.15 & 0.09 & 0.12 & 0.16 & 0.10 & 0.13 & 0.16 & 0.10 & 0.13 \\
\hline Monty & 0.13 & 0.08 & 0.11 & 0.14 & 0.09 & 0.12 & 0.14 & 0.09 & 0.12 \\
\hline Bruno & 0.16 & 0.14 & 0.15 & 0.17 & 0.15 & 0.16 & 0.17 & 0.15 & 0.16 \\
\hline Mean & 0.15 & 0.10 & & 0.16 & 0.11 & & 0.16 & 0.11 & \\
\hline \multicolumn{2}{|c|}{$\mathrm{CD}_{0.05}$} & 2011 & 2012 & Pooled & & & & & \\
\hline \multicolumn{2}{|c|}{ Irrigation treatments (I) } & 0.01 & 0.01 & 0.01 & & & & & \\
\hline \multicolumn{2}{|c|}{ Cultivars (C) } & 0.01 & 0.01 & 0.01 & & & & & \\
\hline \multicolumn{3}{|c|}{ Cultivars (I X C) } & 0.02 & 0.01 & & & & & \\
\hline
\end{tabular}

Table 3. Effect of different irrigation levels on leaf potassium content (\%) of kiwifruit cultivars.

\begin{tabular}{|c|c|c|c|c|c|c|c|c|c|}
\hline \multirow{3}{*}{ Cultivars } & \multicolumn{2}{|c|}{2011} & \multirow{3}{*}{ Mean } & \multicolumn{2}{|c|}{2012} & \multirow{3}{*}{ Mean } & \multirow{2}{*}{\multicolumn{2}{|c|}{$\begin{array}{c}\text { Pooled } \\
\text { Irrigation treatments }\end{array}$}} & \multirow{3}{*}{ Mean } \\
\hline & \multicolumn{2}{|c|}{ Irrigation treatments } & & \multicolumn{2}{|c|}{ Irrigation treatments } & & & & \\
\hline & $80 \%$ FC & $60 \% \mathrm{FC}$ & & $80 \%$ FC & $60 \%$ FC & & $80 \%$ FC & $60 \% \mathrm{FC}$ & \\
\hline Allison & 2.45 & 2.36 & 2.41 & 2.43 & 2.34 & 2.39 & 2.44 & 2.36 & 2.40 \\
\hline Hayward & 2.50 & 2.35 & 2.43 & 2.49 & 2.32 & 2.41 & 2.50 & 2.34 & 2.42 \\
\hline Abbott & 2.37 & 2.29 & 2.33 & 2.36 & 2.26 & 2.31 & 2.37 & 2.28 & 2.32 \\
\hline Monty & 2.16 & 2.06 & 2.11 & 2.15 & 2.00 & 2.08 & 2.16 & 2.03 & 2.10 \\
\hline Bruno & 2.03 & 1.97 & 2.00 & 2.02 & 1.95 & 1.99 & 2.03 & 1.96 & 2.00 \\
\hline Mean & 2.30 & 2.21 & & 2.29 & 2.17 & & 2.30 & 2.19 & \\
\hline $\mathrm{CD}_{0.05}$ & & 2011 & 2012 & Pooled & & & & & \\
\hline \multicolumn{2}{|c|}{ Irrigation treatments (I) } & 0.01 & 0.01 & 0.01 & & & & & \\
\hline \multicolumn{2}{|c|}{ Cultivars (C) } & 0.01 & 0.02 & 0.01 & & & & & \\
\hline \multicolumn{2}{|c|}{$\begin{array}{l}\text { Irrigation treatments } \mathrm{X} \\
\text { Cultivars (I X C) }\end{array}$} & 0.02 & 0.02 & 0.02 & & & & & \\
\hline
\end{tabular}

It is revealed from the Figure 1 that \% decrease in leaf nitrogen content as a result of deficit irrigation treatment was higher in cultivar Hayward $(3.45 \%$ increase over the control), while the reduction in nitrogen content was the least in cultivar Bruno $(2.03 \%)$, followed by the cultivar Allison.

The interaction effect of cultivars and irrigation levels on the leaf nitrogen content was also significant. The cultivar Monty had significantly higher leaf nitrogen content when irrigated at $80 \%$ of field capacity (3.11 and $3.12 \%$ during 2011 and 2012 respectively) than all other cultivars and irrigation treatment combinations, in the respective years. However, the leaf nitrogen content was significantly lowest $(2.09$ and $2.13 \%$ during 2011 and 2012 respectively) in the cultivar Allison when irrigated at $60 \%$ of field capacity, among all other treatment combinations. Similarly, pooled data revealed that leaf nitrogen content was significantly higher in cultivar Monty (3.12\%) under control than all other cultivars irrespective of irrigation treatments and significantly least in cultivar Allison (2.11\%) under deficit irrigation condition.

Phosphorus: The leaf phosphorus content of kiwifruit vines was affected significantly by different irrigation levels during both the years of study (Table 2). During the year 2011, the average leaf phosphorus content of different cultivars was reduced from $0.15 \%$ under control to $0.10 \%$ under deficit irrigation. In the next year, 
Preet Pratima et al. / J. Appl. \& Nat. Sci. 10 (1): 339 - 346 (2018)

Table 4. Effect of different irrigation levels on leaf calcium content (\%) of kiwifruit cultivars.

\begin{tabular}{|c|c|c|c|c|c|c|c|c|c|}
\hline \multirow{3}{*}{ Cultivars } & \multirow{2}{*}{\multicolumn{2}{|c|}{$\begin{array}{c}2011 \\
\text { Irrigation treatments }\end{array}$}} & \multirow{3}{*}{ Mean } & \multicolumn{2}{|c|}{2012} & \multirow{3}{*}{ Mean } & \multicolumn{2}{|c|}{ Pooled } & \multirow{3}{*}{ Mean } \\
\hline & & & & \multicolumn{2}{|c|}{ Irrigation treatments } & & \multicolumn{2}{|c|}{ Irrigation treatments } & \\
\hline & $80 \%$ FC & $60 \%$ FC & & $80 \%$ FC & $60 \%$ FC & & $80 \%$ FC & $60 \% \mathrm{FC}$ & \\
\hline Allison & 3.90 & 3.84 & 3.87 & 3.91 & 3.82 & 3.87 & 3.91 & 3.84 & 3.87 \\
\hline Hayward & 3.82 & 3.72 & 3.77 & 3.83 & 3.71 & 3.77 & 3.83 & 3.72 & 3.77 \\
\hline Abbott & 3.75 & 3.69 & 3.72 & 3.76 & 3.65 & 3.71 & 3.76 & 3.67 & 3.72 \\
\hline Monty & 4.23 & 4.12 & 4.18 & 4.24 & 4.15 & 4.20 & 4.24 & 4.14 & 4.19 \\
\hline Bruno & 3.78 & 3.76 & 3.77 & 3.79 & 3.75 & 3.77 & 3.79 & 3.76 & 3.77 \\
\hline Mean & 3.90 & 3.83 & & 3.90 & 3.82 & & 3.90 & 3.83 & \\
\hline \multicolumn{2}{|l|}{$\mathrm{CD}_{0.05}$} & 2011 & 2012 & Pooled & & & & & \\
\hline \multicolumn{2}{|c|}{ Irrigation treatments (I) } & 0.01 & 0.01 & 0.01 & & & & & \\
\hline \multicolumn{2}{|c|}{ Cultivars (C) } & 0.01 & 0.01 & 0.01 & & & & & \\
\hline \multicolumn{2}{|c|}{$\begin{array}{l}\text { Irrigation treatments X } \\
\text { Cultivars (I X C) }\end{array}$} & 0.02 & 0.01 & 0.01 & & & & & \\
\hline
\end{tabular}

Table 5. Effect of different irrigation levels on leaf magnesium content (\%) of kiwifruit cultivars.

\begin{tabular}{|c|c|c|c|c|c|c|c|c|c|}
\hline \multirow[t]{3}{*}{ Cultivars } & \multicolumn{2}{|c|}{2011} & \multirow[t]{3}{*}{ Mean } & \multicolumn{2}{|c|}{2012} & \multirow[t]{3}{*}{ Mean } & \multicolumn{2}{|c|}{ Pooled } & \multirow[t]{3}{*}{ Mean } \\
\hline & \multicolumn{2}{|c|}{ Irrigation treatments } & & \multicolumn{2}{|c|}{ Irrigation treatments } & & \multicolumn{2}{|c|}{ Irrigation treatments } & \\
\hline & $80 \%$ FC & $60 \%$ FC & & $80 \%$ FC & $60 \% \mathrm{FC}$ & & $80 \%$ FC & $60 \%$ FC & \\
\hline Allison & 0.37 & 0.34 & 0.36 & 0.38 & 0.35 & 0.37 & 0.38 & 0.35 & 0.36 \\
\hline Hayward & 0.36 & 0.30 & 0.33 & 0.37 & 0.31 & 0.34 & 0.37 & 0.31 & 0.34 \\
\hline Abbott & 0.38 & 0.32 & 0.35 & 0.39 & 0.34 & 0.37 & 0.40 & 0.33 & 0.36 \\
\hline Monty & 0.39 & 0.35 & 0.37 & 0.40 & 0.36 & 0.38 & 0.40 & 0.36 & 0.38 \\
\hline Bruno & 0.35 & 0.33 & 0.34 & 0.36 & 0.34 & 0.35 & 0.36 & 0.34 & 0.35 \\
\hline Mean & 0.37 & 0.33 & & 0.38 & 0.34 & & 0.38 & 0.34 & \\
\hline \multicolumn{2}{|l|}{$\mathrm{CD}_{0.05}$} & 2011 & 2012 & Pooled & & & & & \\
\hline \multicolumn{2}{|c|}{ Irrigation treatments (I) } & 0.01 & 0.01 & 0.01 & & & & & \\
\hline \multicolumn{2}{|c|}{ Cultivars (C) } & 0.01 & 0.01 & 0.01 & & & & & \\
\hline \multicolumn{3}{|c|}{ Cultivars (I X C) } & 0.02 & 0.01 & & & & & \\
\hline
\end{tabular}

Table 6. Dates on which irrigation was given to kiwifruit vines under different levels of irrigations (2011).

\begin{tabular}{|c|c|c|c|}
\hline \multicolumn{4}{|c|}{ Irrigation levels } \\
\hline \multicolumn{2}{|c|}{ Irrigation at $80 \%$ FC } & \multicolumn{2}{|c|}{ Irrigation at $60 \%$ FC } \\
\hline Date of irrigation & Interval (days) & Date of irrigation & Interval (days) \\
\hline 15.03 .2011 & - & 15.03 .2011 & - \\
\hline 22.03 .2011 & 7 & 25.03 .2011 & 10 \\
\hline 29.03 .2011 & 7 & 12.04 .2011 & 18 \\
\hline 05.04 .2011 & 7 & 10.05 .2011 & 28 \\
\hline 19.04.2011 & 14 & 24.05.2011 & 14 \\
\hline 03.05 .2011 & 14 & 21.06 .2011 & 28 \\
\hline 17.05.2011 & 14 & 30.07 .2011 & 39 \\
\hline 31.05 .2011 & 14 & 12.08 .2011 & 13 \\
\hline 14.06 .2011 & 14 & 14.09 .2011 & 33 \\
\hline 28.06.2011 & 14 & 11.10 .2011 & 27 \\
\hline 26.07.2011 & 28 & 10 & \\
\hline 16.08 .2011 & 21 & & \\
\hline 06.09 .2011 & 21 & & \\
\hline 27.09 .2011 & 21 & & \\
\hline 11.10 .2011 & 14 & & \\
\hline 18.10 .2011 & 7 & & \\
\hline 16 & & & \\
\hline
\end{tabular}

again leaf phosphorus content decreased significantly to $0.11 \%$ under water stress treatment compared to $0.16 \%$ in control. The pooled data also revealed that the leaf phosphorus content decreased significantly with deficit irrigation in comparison to control.

Leaf phosphorus content of different cultivars maintained under different soil water regimes also varied significantly. During the year 2011, significantly highest leaf phosphorus content $(0.15 \%)$ was recorded jointly in cultivars Bruno and Allison, among all the cultivars. During the year 2012, again uppermost level of the leaf phosphorus $(0.16 \%)$ was noticed in these two cultivars, which was significantly higher as compared to the remaining cultivars. However, during both the years, the phosphorus content was observed to be significantly lower $(0.10$ and $0.11 \%$ in 2011 and 2012, respectively) in cultivar Hayward as compared to the remaining cultivars, except, Monty. Likewise, 
Preet Pratima et al. / J. Appl. \& Nat. Sci. 10 (1): 339 - 346 (2018)

Table 7. Dates on which irrigation was given to kiwifruit vines under different levels of irrigations (2012).

\begin{tabular}{|c|c|c|c|}
\hline \multicolumn{4}{|c|}{ Irrigation levels } \\
\hline \multicolumn{2}{|c|}{ Irrigation at $80 \%$ FC } & \multicolumn{2}{|c|}{ Irrigation at $60 \% \mathrm{FC}$} \\
\hline Date of irrigation & Interval (days) & Date of irrigation & Interval (days) \\
\hline 14.03 .2012 & - & 14.03 .2012 & - \\
\hline 20.03.2012 & 6 & 23.03.2012 & 9 \\
\hline 27.03.2012 & 7 & 11.04.2012 & 19 \\
\hline 04.04.2012 & 8 & 07.05 .2012 & 26 \\
\hline 18.04.2012 & 14 & 23.05.2012 & 16 \\
\hline 02.05 .2012 & 14 & 21.06.2012 & 29 \\
\hline 16.05.2012 & 14 & 1.08 .2012 & 41 \\
\hline 12.06.2012 & 27 & 11.08 .2012 & 10 \\
\hline 25.06.2012 & 13 & 14.09.2012 & 34 \\
\hline 13.07.2012 & 18 & 10.10 .2012 & 26 \\
\hline 28.07.2012 & 15 & 10 & \\
\hline 14.08.2012 & 17 & & \\
\hline 14.09.2012 & 31 & & \\
\hline 25.09.2012 & 11 & & \\
\hline 08.10 .2012 & 13 & & \\
\hline 19.10.2012 & 11 & & \\
\hline 16 & & & \\
\hline
\end{tabular}

pooled data revealed that leaf phosphorus content was significantly highest $(0.16 \%)$ jointly in cultivars Bruno and Allison compared to the remaining cultivars and the significantly lower in cultivar Hayward in compared to the remaining cultivars except, Monty.

It is revealed from the Fig. 2 that the \% reduction in leaf phosphorus content due to the deficit irrigation (irrigation at $60 \%$ FC) was more in cultivar Hayward $(55.2 \%)$ over the control and the least in cultivar Bruno (12.2\%), followed by the cultivar Allison (22.9).

Potassium: It is evident from the data (Table 3 ) that leaf potassium content was influenced significantly by different irrigation levels during both the years of study. Leaf potassium content decreased significantly when the vines were subjected to water stress by applying deficit irrigation at $60 \%$ of field capacity. During the year 2011, the average leaf potassium content of different cultivars was decreased significantly from $2.30 \%$ under irrigation at $80 \%$ of field capacity to $2.21 \%$ under irrigation at $60 \%$ of field capacity. Similarly, leaf potassium content decreased significantly from $2.29 \%$ in control to $2.17 \%$ under water stress treatment, in the year 2012 at $0.05 \%$ level of significance. The pooled data also revealed that the leaf potassium content decreased significantly following deficit irrigation $(2.30 \%)$ in comparison to control $(2.19 \%)$. Leaf potassium content of kiwifruit cultivars differed significantly when their vines were maintained under two different water regimes, during both the years of study. The leaf potassium content of cultivar Hayward was significantly higher (2.43 and $2.41 \%$ in 2011 and 2012, respectively) than all other cultivars except, "Allison" in 2012. However, the leaf potassium content was significantly lowest $(2.0$ and $1.99 \%$ in 2011 and 2012, respectively) in cultivar Bruno, among all other cultivars. Similarly, pooled data revealed that leaf potassium content was significantly higher in cul- tivar Hayward than all other cultivars and significantly least in cultivar Bruno.

The $\%$ decrease in leaf potassium level due to deficit irrigation was more in cultivar Hayward (6.40 \%) over the control, while the decrease in leaf potassium content due to deficit irrigation over irrigation at $80 \%$ of FC was the least (3.23\%) in cultivar Bruno (Fig. 3).

Calcium: The leaf calcium contents of kiwifruit cultivars were influenced significantly by different irrigation levels (Table 4). The leaf calcium content decreased with the deficit irrigation treatment compared with regular irrigation (control). During the year 2011, the average leaf calcium content of different cultivars was decreased significantly from $3.90 \%$ under irrigation at $80 \%$ of field capacity to $3.83 \%$ under irrigation at $60 \%$ of field capacity. Similarly in the year 2012, leaf calcium content decreased significantly from 3.90 $\%$ in control to $3.82 \%$ under water stress treatment. The pooled data also revealed that the calcium content decreased significantly following deficit irrigation $(3.83 \%)$ in comparison to control $(3.90 \%)$. Leaf calcium content of kiwifruit cultivars under two water regimes differed significantly, during both the years of study. Average leaf calcium content of the cultivar Monty (4.18 and 4.20\% in 2011 and 2012, respectively) was significantly higher than all other cultivars. However, the level of leaf calcium was significantly lowest (3.72 and 3.71\% in 2011 and 2012, respectively) in cultivar Abbott, among all other cultivars. It is revealed from the Figure 4 that the \% decrease in the leaf calcium level as a result of deficit irrigation treatment was more pronounced in cultivar Hayward (2.81 $\%$ ), while the reduction in calcium content due to deficit irrigation was the least in cultivar Bruno $(0.73 \%)$.

Magnesium: The perusal of the data (Table 5) reveals that the leaf magnesium content of kiwifruit cultivars was affected significantly by deficit irrigation in com- 
parison to control. The average leaf magnesium content of different cultivars was reduced from $0.37 \%$ under regular irrigation to $0.33 \%$ under deficit irrigation treatment, during the year 2011. In the next year, again the water stress treatment decreased the leaf magnesium content significantly $(0.38 \%)$ as compared to control $(0.34 \%)$. Different cultivars varied significantly with respect to leaf magnesium content under two water regimes. In both the years, leaf magnesium content was recorded significantly higher in cultivar Monty (0.37 and $0.38 \%$ in 2011 and 2012, respectively) which was however, statistically at par with "Allison" and "Abbott". However, magnesium content was observed lowest $(0.33$ and $0.34 \%$ in 2011 and 2012, respectively) in cultivar Hayward, which was however, statistically at par with "Bruno" and "Abbott" in 2011 and "Bruno" in 2012. Likewise, pooled data revealed that leaf magnesium content was significantly highest in cultivar Monty. Its average value was observed least in cultivar Hayward, which was however, statistically at par with "Bruno". It is evident from the Figure 5 that the \% reduction in leaf magnesium content due to the deficit irrigation treatment was highest in cultivar Hayward (16.2\%), and the least in cultivar Bruno (5.6\% over the control).

It is clear from this investigation that the leaf nutrient contents were greatly variable among the different kiwifruit cultivars irrespective of soil moisture regime. The decrease in soil moisture decreased the level of leaf nutrients by affecting the concentrations of elements in soil solution, nutrient uptake and translocation (Rimski- Korsakov et al., 2009; Salisbury and Ross, 1992). These findings are in conformity with those of Sanjeev (2006) in pear rootstocks and Shaheen et al., (2011) in olives, as they also observed that water stress decreased the leaf nutrient levels, which was however, more marked in drought sensitive plants. The decrease in leaf magnesium content in response to drought stress is in line with the findings of Romero et al. (2006) in Clemenules mandarine.

Frequency and number of irrigation: The data pertaining to the frequency and number of irrigations applied at $80 \%$ and $60 \% \mathrm{FC}$ are presented in Table 6 and Table 7. During the year 2011, the first irrigation was applied to all of the experimental vines on $15^{\text {th }}$ March (Table 6). The interval between first and second irrigation was 7 and 10 days in the irrigation treatment given at $80 \%$ and $60 \% \mathrm{FC}$, respectively. The irrigation intervals in the month of April, May, June and July however, varied from 14 to 21 and 14 to 28 days under the irrigation treatments given at $80 \%$ and $60 \%$ FC, respectively. During 2012, the first irrigation was applied on $14^{\text {th }}$ March and the interval between first and second irrigation was 6 and 9 days under the irrigation treatments given at $80 \%$ and $60 \% \mathrm{FC}$, respectively (Table 7). In the months of March and April, the irrigation intervals under the treatments applied at 80
$\%$ and $60 \% \mathrm{FC}$ varied from 6 to 14 and 9 to 19 days, respectively. Thereafter from May to July, irrigation intervals varied from 14 to 18 and 26 to 29 days, respectively under the irrigation treatments applied at 80 $\%$ and $60 \%$ FC. In the month of August, intervals between subsequent irrigations increased to 17 and 41 days under irrigation treatments given at $80 \%$ and 60 $\%$ FC, respectively. During the course of study in 2011 and 2012, in all the cultivars the total number of irrigations applied under irrigation treatments given at $80 \%$ and $60 \% \mathrm{FC}$ were 16 and 10, respectively.

\section{Conclusion}

The present study suggests that the kiwifruit leaf $\mathrm{N}, \mathrm{P}$, $\mathrm{K}, \mathrm{Ca}$ and $\mathrm{Mg}$ contents varied with cultivars under two irrigation regimes. These nutrient contents reduced significantly with deficit irrigation treatment in different cultivars, and the \% reduction in these nutrients was found to be highest in Hayward and the least in Bruno. The total number of irrigation applied under standard and deficit irrigation was 16 and 10 respectively, during both the years. Thus, the cultivar Bruno exhibited better adaptability to water scarce condition than the other mentioned cultivars.

\section{REFERENCES}

AOAC (1980). Official Methods of Analysis of the Analytical Chemists $13^{\text {th }}$ ed. Horowitz W. (ed.). Association of official Analytical Chemists, Washington, D.C.

Amtmann, A., Troufflard, S. and Armengaud, P. (2008). The effect of potassium nutrition on pest and disease resistance in plants. Physiol. Plantarum. 133: 682-691.

Anonymous (2005). Kiwifruit. www.nhb.gov.in/modelproject-reports/index.html

Beutel, J.A. (1990). Kiwifruit, In: Advances in new crops. J. Janick and J.E. Simon (eds.). Timber Press, Portland, O. R., pp 309-316.

Blum, A. (2011). Plant Breeding for Water- Limited Environments. Springe New York.

Chapman, H. D. (1964). Suggested foliar sampling and handling techniques for determining the nutrient status of some field, horticultural and plantation crops. Ind. J. of Hortic. 21 (2): 97-119.

Clarkson, D. T., Carvajal, M., Henzler, T., Waterhouse, R. N., Smyth, A. J., Cooke, D. T. and Steudle, E. (2000). Root hydraulic conductance: diurnal aquaporin expression and the effects of nutrient stress. J. of Exp. Bot. 51: $61-70$.

Cochran, G. C. and Cox, G. M. (1963). Experimental Design. Asia Publishing House, Bombay.

De Groot, C. C., Marcelis, L. F. M., Van den Boogaard, R. and, Lambers H. (2001). Growth and dry-mass partitioning in tomato as affected phosphorus nutrition and light. Plant, Cell and Envi. 24: 1309-1317.

Ferguson, A. R. (1984). Kiwifruit: a botanical review. Horticultural Rev. 6: 1-64.

Gomez K A and Gomez A A. (1984). Statistical Procedures for Agricultural Research. John Willey and Son, New York.

Jackson, M. L. (1973). Soil chemical analysis. Prentire Hall India Pvt. Ltd. New Delhi. Rimski-Korsakov, H., Ru- 
bio, G. and Lavado, R.S. (2009). Effect of water stress in maize crop production and nitrogen fertilizer fate. $J$. of Plant Nut. 32: 565-578.

Jacob, J., Lawlor, D. W. (1992). Dependence of photosynthesis of sunflower and maize on phosphate supply, ribulose-1,5-biphospahte carboxylase/oxygenase activity, and ribulose-1, 5-biphosphate pool size. Plant Physiol. 98: 801-807.

Kenworthy, A. L. (1964). Fruit, nut and plantation crops, deciduous and evergreen. A guide for collecting foliar samples for nutrient element analysis. Memo. Horticultural Department Michigan State University, Michigan, pp 223-224.

Lynch, J., Lauchli, A. and Epstein, E. (1991). Vegetative growth of common bean in response to phosphorus nutrition. Crop Sci. 31: 380-387.

Marschner, P. (2012). Marschner's Mineral Nutrition of Higher Plants 3rd ed. Academic Press; London, U. K., pp. 178-189.

Miller, S. A. Smith, G. S., Boldingh, H. L. and Johansson, A. (1998). Effects of water stress on Fruit quality attributes of kiwifruit. Annals of Bot. 81:73-81.

Min W., Qingsong Z., Qirong S. and Shiwei, G. (2013). The Critical Role of Potassium in Plant Stress Response. Int J. Mol. Sci. 14(4): 7370-7390.

Munns, R., Passioura, J. B., Guo, J., Chazen, O. and Cramer, G. R. (2000). Water relations and leaf expansion: importance of time scale. J. of Exp. Bot. 51: 1495 -1504.

Piper, C. S. (1966). Soil and Plant Analysis. Hans Publications, Bombay, India.
Romero, P., Navarro, J. M., Perrez Perrez, J. Garcia-Sanchez, F., Gomez- Gomez, A., Porras, I., Martinez, V. and Botia, P. (2006). Deficit irrigation and rootstock: their effects on water relations, vegetative development, yield, fruit quality and mineral nutrition of Clemenules mandarin. Tree Physiol. 26: 1537-1548.

Salisbury, F. B. and Ross, C. W. (1992). Environmental physiology, In: Plant Physiology. 4th Edition. Wadsworth Pub. Company. Belmont. CA. USA, pp 549 -600 .

Sanjeev. (2006). Influence of rootstocks and paclobutrazol on growth and physiology of pear cv. Flemish beauty under different soil moisture regimes. Ph.D thesis, Dr.Y.S.Parmar University of Horticulture and Forestry, Nauni.Solan, HP. India

Seyed, Y. S. L., Rouhollah, M., Mosharraf, M. H. and Ismail, M. M. R. (2012). Water Stress. In:, Water Stress in Plants: Causes, Effects and Responses. Ismail, M. M. R. and Hiroshi, H. (eds.). InTech, Rijeka, Croatia, pp.1-14.

Shabala, S. and Pottosin, I.I. (2010). Potassium and potassium-permeable channels in plant salt tolerance. Signal. Commun. Plants. 87-110.

Shaheen, M. A., Hegazi, A. A. and Humam, I. S. A. (2011). Effect of water stress on vegetative characteristics and leaves chemical constituents of some transplants olive cultivars. Amer.- Euras. J. of Agri. and Environental. Sci. 11(5): 663-670.

White, P. and Karley, A. (2010). Potassium. In: Cell Biology of Metals and Nutrients. Hell, R. and Mendel, R. R (eds.). Springer, Berlin/Heidelberg, Germany, 199-224. 